\title{
Analiza pacjentów leczonych protetycznie we wrocławskiej klinice w latach 2006-2013 z powodu urazów twarzoczaszki
}

\author{
Analysis of patients treated prosthetically in a clinic in Wroclaw \\ from 2006 to 2013 following craniofacial injuries
}

\author{
${ }^{1}$ Katedra Protetyki Stomatologicznej Uniwersytetu Medycznego im. Piastów Śląskich we Wrocławiu \\ ${ }^{2}$ Student Śląskiego Uniwersytetu Medycznego w Katowicach
}

DOI: http://dx.doi.org/10.20883/df.2017.22

\begin{abstract}
Streszczenie
Wprowadzenie. Urazy twarzoczaszki to jedne z częściej występujących obrażeń kwalifikujących się do leczenia protetycznego. Mogą dotyczyć prawej lub lewej szczęki, obu szczęk, a także żuchwy - zarówno u kobiet, jak i mężczyzn. W takich przypadkach istnieje potrzeba przeprowadzenia leczenia protetycznego.

Cel. Analiza pacjentów pourazowych, leczonych protetycznie w Katedrze i Zakładzie Protetyki Stomatologicznej Wrocławskiego Uniwersytetu Medycznego w latach 2006-2013.

Materiał i metody. Badaną grupę stanowiło 61 pacjentów (16 mężczyzn i 45 kobiet) z obrażeniami w obrębie twarzoczaszki. U zgłaszających się do leczenia przeprowadzano wywiad ogólnomedyczny i stomatologiczny, badanie zewnątrzi wewnątrzustne, badanie radiologiczne, a następnie ustalano plan i przeprowadzano indywidualnie dobraną terapię.

Wyniki. 1. W badanym okresie do pourazowego leczenia protetycznego zgłosiło się zdecydowanie więcej kobiet niż mężczyzn. 2. Najwięcej pacjentów pochodziło z Wrocławia i stanowili oni 47,6\% leczonych. 3. Wypadki komunikacyjne były przyczyną 52,4\% urazów. 4. Obrażenia najczęściej dotyczyły żuchwy i wystąpiły u 77,04\% pacjentów. 5. Wzrost napięcia mięśni najczęściej występował obustronnie i dotyczył 37,7\% leczonych pacjentów. 6 . Leczenie protetyczne w 47,5\% przypadków obejmowało lewy i prawy staw skroniowo-żuchwowy. 7 . Podstawową metodą leczenia protetycznego pacjentów po urazach twarzoczaszki było wykonywanie szyn odciążających w 81,9\% przypadków.

Wnioski. Należy stwierdzić, że u wszystkich pacjentów po przeprowadzeniu odpowiedniego leczenia protetycznego obejmującego wykonanie szyny odciążającej oraz po wspomagających zabiegach fizjoterapeutycznych (takich jak ćwiczenia mięśniowe Gerry’ego oraz masaże mięśni) dolegliwości ustąpiły najpóźniej 3 miesiące od rozpoczęcia leczenia.
\end{abstract}

Słowa kluczowe: uraz twarzoczaszki, leczenie protetyczne, szyna odciążająca.

\begin{abstract}
Introduction. Craniofacial trauma is a common form of injury. It can affect the right maxilla and/or left maxilla and/or mandible both in women and men. In such cases there is a need for prosthetic treatment.

Aim. To present an analysis of prosthodontically treated post-traumatic patients from the years 2006-2013 in the Chair and Department of Dental Prosthetics at Wroclaw Medical University.

Material and Methods. The studied group consisted of 61 post-traumatic patients, including 16 men and 45 women. The patients were interviewed and examined. Each patient was referred for radiological examination, and then a plan of prosthetic treatment was established and performed.

Results. 1. In the studied period of time more women than men were reported to need post-traumatic prosthetic treatment. 2. The majority of patients were from Wroclaw (47.6\%). 3. Traffic accidents were the cause of $52.4 \%$ of the injuries that needed post-traumatic prosthetic treatment. 4 . The most common injuries, in $77.04 \%$ of the patients, occurred in the mandible. 5 . Increased muscle tension occurred on both sides in $37.7 \%$ of the treated patients. 6 . In $47.5 \%$ of the cases prosthetic treatment focused on the left and right temporomandibular joint. 7 . The basic method of prosthetic treatment for post-traumatic patients after craniofacial injuries was the use of relieving splints (81.9\%).

Conclusions. It should be noted that after performing the appropriate prosthetic treatment involving the implementation of a relief plate and supportive physiotherapeutic procedures such as Gerry's muscular exercises and muscle massage, all post-traumatic ailments subsided for up to 3 months after the beginning of treatment for all patients.
\end{abstract}

Keywords: craniofacial trauma, prosthetic treatment, relieving splints.

\section{Wstęp}

Urazy w zakresie twarzoczaszki należą do częstych przyczyn kwalifikujących do leczenia protetycznego. Urazy te mogą dotyczyć wyłącznie pra- wej szczęki lub lewej szczęki, obu szczęk, a także żuchwy i to z różną częstotliwością u kobiet jak i u mężczyzn [1-4], niezależnie od wieku. Pacjenci pourazowi trafiający do leczenia pochodzą za- 
równo $z$ dużych i średnich miast, jak też z małych miasteczek i wsi. Podczas konsultowania pacjenta pourazowego zazwyczaj badane są przyczyny zaistnienia konieczności pourazowego leczenia protetycznego, zasięg odwodzenia żuchwy, okolice urazu oraz napięcie mięśni twarzy [5-7]. Wykonuje się kontrolne zdjęcie lewego i prawego stawu skroniowo-żuchwowego według Schillera lub stożkową tomografię komputerową, a także małoobrazkowe zdjęcia izometryczne i ortoradialne wybranych zębów [8-11]. Leczenie protetyczne prowadzone u pacjentów pourazowych zazwyczaj opiera się na wykonaniu szyny odciążającej, ćwiczeniach Gerrey'ego polegających na wzmacnianiu mięśni dna jamy ustnej i masażu mięśni [12-15]. Bardzo często uraz w obrębie twarzoczaszki może być skorelowany $z$ urazem kręgów szyjnych, kręgów piersiowych lub/i obręczy barkowej, w związku z czym często wymaga leczenia wielopoziomowego. Należy podkreślić, że przy znacznej liczbie pacjentów pourazowych trafiających do leczenia protetycznego jedynie niewielu rezygnuje z leczenia po konsultacji.

\section{Cel}

Celem pracy była analiza protetycznie leczonych pacjentów pourazowych zgłaszających się w latach 2006-2013 do Wrocławskiego Uniwersytetu Medycznego.

\section{Materiał i metody}

Badaną grupę stanowiło 61 osób z urazami w zakresie twarzoczaszki (w wieku od 15 do 82 lat, w tym 45 kobiet i 16 mężczyzn), którzy zostali przyjęci do leczenia protetycznego w Katedrze i Zakładzie Protetyki Stomatologicznej Wrocławskiego Uniwersytetu Medycznego im. Piastów Ślą-

Tabela 1. Charakterystyka liczbowa pacjentów leczonych protetycznie po urazach w obrębie twarzoczaszki uwzględniająca płeć

Table 1. Characteristics of patients treated prosthetically after craniofacial injury

\begin{tabular}{|l|l|}
\hline \multicolumn{1}{|c|}{ Kobiety } & 45 \\
\hline Mężczyźni & 16 \\
\hline Razem & 61 \\
\hline
\end{tabular}

skich (Tabela 1). U zgłaszających się pacjentów przeprowadzano wywiad ogólnomedyczny i stomatologiczny, badanie zewnątrz- i wewnątrzustne, niezbędne badania radiologiczne, a następnie ustalano plan i przeprowadzano leczenie protetyczne. Pacjentów podzielono ze względu na płeć, wiek, pochodzenie, typ i przyczynę urazu i przeanalizowano uzyskane dane.

\section{Wyniki}

Do grupy wiekowej od 15 do 20 lat zakwalifikowano 6 osób, w tym 4 kobiety i 2 mężczyzn. W grupie wiekowej od 21 do 25 lat znalazło się 11 osób, w tym 6 kobiet i 5 mężczyzn. Do grupy wiekowej od 26 do 30 lat zakwalifikowano 9 osób, w tym 6 kobiet i 3 mężczyzn. W grupie wiekowej od 31 do 35 lat znalazło się 10 pacjentów, w tym 8 kobiet i 2 mężczyzn. W grupie wiekowej od 36 do 40 lat leczono 6 osób, w tym 5 kobiet i 1 mężczyznę. W grupach wiekowych od 41 do 45 lat i od 46 do 50 lat leczono po 3 pacjentów, po 2 kobiety i po 1 mężczyźnie. W grupie wiekowej od 51 do 55 lat leczono 3 osoby i były to same kobiety. W przedziale wiekowym od 56 do 60 lat leczono 6 pacjentów i były to same kobiety. W przedziale wiekowym od 61 do 65 lat była 1 pacjentka. W przedziale wiekowym od 66 do 70 lat leczono 2 pacjentki. W przedziale wiekowym powyżej 71 lat znalazł się tylko jeden, 82-letni pacjent. Podsumowując, należy stwierdzić, że najwięcej pacjentów pourazowych było w wieku od 21 do 35 lat. Na podkreślenie zasługuje fakt, że nie zgłosił się ani jeden mężczyzna w wieku od 51 do 70 lat $z$ urazem (Tabela 2).

Pacjenci pochodzili w większości z Wrocławia (29 osób). Wśród nich znalazło się 21 kobiet i 8 mężczyzn. Z Piławy Górnej i Siechnic pochodziły po 2 kobiety. Pojedyncze pacjentki pochodziły z Biestrzykowa, Bogdaszowic, Brzezińca, Brzezinki, Bytomia, Kudowy Zdroju, Łosic, Łowęcić, Malczyc, Nowej Soli, Nowogrodźca, Opola, Pakosławska, Plgowa, Raciborza, Radwanic, Smolca, Strzelina, Zaułka Rogozińskiego i Zebrzydowej. Pojedynczy pacjenci pochodzili z Czermy, Kiełczowa, Krotoszyna, Namysłowa, Sobótki, Środy Śląskiej, Świdnicy i Wielunia (Tabela 3).

Podczas badania ustalono, że u kobiet najmniejszy zasięg odwodzenia żuchwy wynosił 22

Tabela 2. Zestawienie leczonych pacjentów ze względu na wiek i płeć

Table 2. Summary of patients treated for age and sex

\begin{tabular}{|l|c|c|c|c|c|c|c|c|c|c|c|c|}
\hline $\begin{array}{c}\text { Przedziały } \\
\text { wiekowe }\end{array}$ & $15-20$ & $21-25$ & $26-30$ & $31-35$ & $36-40$ & $41-45$ & $46-50$ & $51-55$ & $56-60$ & $61-65$ & $66-70$ & Powyżej 71 \\
\hline Kobiety & 4 & 6 & 6 & 8 & 5 & 2 & 2 & 3 & 6 & 1 & 2 & - \\
\hline Mężczyźni & 2 & 5 & 3 & 2 & 1 & 1 & 1 & - & - & - & - & 1 \\
\hline Razem & 6 & 11 & 9 & 10 & 6 & 3 & 3 & 3 & 6 & 1 & 2 & 1 \\
\hline
\end{tabular}


Tabela 3. Miejsca zamieszkania leczonych pacjentów

Table 3. Residence of treated patients

\begin{tabular}{|c|c|c|c|c|}
\hline Miejsca zamieszkania kobiet & llość & Miejsca zamieszkania mężczyzn & Ilość & Razem \\
\hline Wrocław & 21 & Wrocław & 8 & 29 \\
\hline Piława Górna & 2 & & & 2 \\
\hline Siechnice & 2 & & & 2 \\
\hline Bieszczyków & 1 & & & 1 \\
\hline Bogdaszowice & 1 & & & 1 \\
\hline Brzeziniec & 1 & & & 1 \\
\hline Brzezinka & 1 & & & 1 \\
\hline Bytom & 1 & & & 1 \\
\hline Kudowa Zdrój & 1 & & & 1 \\
\hline Łosice & 1 & & & 1 \\
\hline Łowęcice & 1 & & & 1 \\
\hline Malszyce & 1 & & & 1 \\
\hline Nowa Sól & 1 & & & 1 \\
\hline Nowogrodziec & 1 & & & 1 \\
\hline Opole & 1 & & & 1 \\
\hline Pakosławsko & 1 & & & 1 \\
\hline Plgów & 1 & & & 1 \\
\hline Racibórz & 1 & & & 1 \\
\hline Radwanice & 1 & & & 1 \\
\hline Smolec & 1 & & & 1 \\
\hline Strzelin & 1 & & & 1 \\
\hline Zaułek Rogoziński & 1 & & & 1 \\
\hline \multirow[t]{9}{*}{ Zebrzydowa } & 1 & & & 1 \\
\hline & & Czerna & 1 & 1 \\
\hline & & Kiełczów & 1 & 1 \\
\hline & & Krotoszyn & 1 & 1 \\
\hline & & Namysłów & 1 & 1 \\
\hline & & Sobótka & 1 & 1 \\
\hline & & Środa Śląska & 1 & 1 \\
\hline & & Świdnica & 1 & 1 \\
\hline & & Wieluń & 1 & 1 \\
\hline
\end{tabular}

$\mathrm{mm}$, a największy $55 \mathrm{~mm}$. Natomiast u mężczyzn najmniejszy zasięg odwodzenia żuchwy wynosił $20 \mathrm{~mm}$, a największy $61 \mathrm{~mm}$. Należy podkreślić, że zasięg odwodzenia żuchwy do $39 \mathrm{~mm}$ wystąpił w 32 przypadkach (u 24 kobiet i u 8 mężczyzn). Natomiast zasięg odwodzenia żuchwy powyżej 40 $\mathrm{mm}$ wystąpił w 29 przypadkach, w tym u 21 kobiet i 8 mężczyzn (Tabela 4).

Z przeprowadzonych wywiadów wynikało, że przyczyną pourazowego leczenia protetycznego były w 32 przypadkach wypadki komunikacyjne, w znacznej większości u kobiet (28 dotyczyło kobiet i 4 mężczyzn). U następnych 13 osób stwierdzono pobicie (5 kobiet i 8 mężczyzn). Uderzenie spowodowane potknięciem wystąpiło u 8 pacjentów (w tym u 5 kobiet i 3 mężczyzn). Uprawianie sportu doprowadziło do leczenia 6 pacjentów (5 kobiet i 1 mężczyzny). Natomiast po jatrogennych wygojonych złamaniach żuchwy do leczenia trafiły 2 kobiety (Tabela 5).
Pacjenci z urazem szczęki to 9 osób (w tym 6 kobiet i 3 mężczyzn). Natomiast pacjenci z urazem żuchwy to 47 osób (w tym 37 kobiet i 10 mężczyzn). Uraz jednoczesny szczęki i żuchwy dotyczył 5 pacjentów (w tym 2 kobiet i 3 mężczyzn) (Tabela 6).

Wzrost napięcia mięśni twarzy po stronie lewej stwierdzono w 13 przypadkach (12 kobiet i 1 mężczyzny). Po stronie prawej wzrost napięcia mięśni twarzy wystąpił w 11 przypadkach (w 7 u kobiet i 4 u mężczyzn). Obustronny wzrost napięcia wystąpił w 23 przypadkach (w tym u 18 kobiet i 5 u mężczyzn). Należy podkreślić, że wzrost napięcia mięśni po urazie nie wystąpił u 14 chorych (8 kobiet i 6 mężczyzn) (Tabela 7).

Leczenie protetyczne obejmujące lewy staw skroniowo-żuchwowy zastosowano u 18 pacjentów (w tym 17 kobiet i 1 mężczyzny). Leczenie protetyczne prawego stawu skroniowo-żuchwowego było konieczne u 14 pacjentów (8 kobiet i 8 mężczyzn). Zarówno lewy, jak i prawy staw skronio- 
Tabela 4. Zasięg odwodzenia żuchwy w badaniu klinicznym

Table 4. Depression of the mandible in a clinical trial

\begin{tabular}{|l|c|c|}
\hline & Zasięg do $39 \mathrm{~mm}$ & Zasięg powyżej $40 \mathrm{~mm}$ \\
\hline Kobiety & 24 & 21 \\
\hline Mężczyźni & 8 & 8 \\
\hline Razem & 32 & 29 \\
\hline
\end{tabular}

Tabela 5. Przyczyny urazów zakwalifikowanych do leczenia protetycznego u kobiet i mężczyzn

Table 5. Causes of injuries classified for prosthetic treatment in women and men

\begin{tabular}{|l|c|c|c|c|c|}
\hline $\begin{array}{c}\text { Przyczyny leczenia } \\
\text { protetycznego }\end{array}$ & $\begin{array}{c}\text { Wypadki } \\
\text { komunikacyjne }\end{array}$ & Pobicie & $\begin{array}{c}\text { Uderzenie spowodowane } \\
\text { potknięciem }\end{array}$ & Sport & $\begin{array}{c}\text { Po jatrogennym wygojonym } \\
\text { złamaniu żuchwy }\end{array}$ \\
\hline Kobiety & 28 & 5 & 5 & 5 & 2 \\
\hline Mężczyźni & 4 & 8 & 3 & 1 & - \\
\hline Razem & 32 & 13 & 8 & 6 & 2 \\
\hline
\end{tabular}

Tabela 6. Umiejscowienie urazu u kobiet i mężczyzn

Table 6. Location of injury in men and women

\begin{tabular}{|l|c|c|c|}
\hline & Szczęka & Żuchwa & Szczęka i żuchwa \\
\hline Kobiety & 6 & 37 & 2 \\
\hline Mężczyźni & 3 & 10 & 3 \\
\hline Razem & 9 & 47 & 5 \\
\hline
\end{tabular}

Tabela 7. Lokalizacja pourazowego wzrostu napięcia mięśni twarzy u kobiet i mężczyzn

Table 7. Location of posttraumatic tension in facial muscles in men and women

\begin{tabular}{|l|c|c|c|c|}
\hline & Strona lewa & Strona prawa & Strona lewa i prawa & Bez wzrostu napięcia \\
\hline Kobiety & 12 & 7 & 18 & 8 \\
\hline Mężczyźni & 1 & 4 & 5 & 6 \\
\hline Razem & 13 & 11 & 23 & 14 \\
\hline
\end{tabular}

Tabela 8. Konieczność leczenia protetyczngo w obrębie stawów skroniowo-żuchwowych

Table 8. Prosthetic treatment in temporomandibular joints

\begin{tabular}{|l|c|c|c|}
\hline & Staw skroniowo-żuchwowy lewy & Staw skroniowo-żuchwowy prawy & $\begin{array}{c}\text { Staw skroniowo-żuchwowy } \\
\text { lewy i prawy }\end{array}$ \\
\hline Kobiety & 17 & 8 & 20 \\
\hline Mężczyźni & 1 & 6 & 9 \\
\hline Razem & 18 & 14 & 29 \\
\hline
\end{tabular}

Tabela 9. Rodzaje przeprowadzonego leczenia u kobiet i mężczyzn

Table 9. Types of treatment performed in men and women

\begin{tabular}{|l|c|c|c|c|}
\hline & $\begin{array}{c}\text { Wykonane szyny } \\
\text { odciążające }\end{array}$ & $\begin{array}{c}\text { Wykonywanie ćwiczeń } \\
\text { Gerrey'ego }\end{array}$ & Masaż mięśni & Odstąpienie od leczenia \\
\hline Kobiety & 37 & 2 & 2 & 6 \\
\hline Mężczyźni & 13 & 2 & 1 & 2 \\
\hline Razem & 50 & 4 & 3 & 8 \\
\hline
\end{tabular}

wo-żuchwowy trzeba było objąć leczeniem w 29 przypadkach (20 kobiet i 9 mężczyzn) (Tabela 8).

W 50 przypadkach u pacjentów poddanych leczeniu wykonano szyny odciążające (w tym u 37 kobiet i u 13 mężczyzn). Ćwiczenia Gerry'ego zalecono w 4 przypadkach (w tym u 2 kobiet i 2 mężczyzn). Masaż mięśni zalecono 3 pacjentom, (2 kobietom oraz 1 mężczyźnie) (Tabela 9).

$\mathrm{Na}$ różnych etapach z leczenia zrezygnowało 8 osób, 6 kobiet i 2 mężczyzn. Należy podkreślić, że 
u wszystkich pacjentów poddanych leczeniu nastąpiła poprawa najpóźniej 3 miesiące od rozpoczęcia leczenia.

\section{Podsumowanie}

W latach 2006-2013 do pourazowego leczenia protetycznego we wrocławskiej klinice zgłosiło się zdecydowanie więcej kobiet niż mężczyzn. Najwięcej pacjentów pochodziło z Wrocławia, stanowili oni $47,6 \%$ leczonych. Wypadki komunikacyjne były przyczyną 52,4\% urazów. Obrażenia najczęściej dotyczyły żuchwy i występowały u 77,04\% pacjentów. Wzrost napięcia mięśni twarzy najczęściej występował obustronnie i dotyczył $37,7 \%$ przyjętych pacjentów. Leczenie protetyczne w $47,5 \%$ przypadków obejmowało lewy i prawy staw skroniowo-żuchwowy. Podstawową metodą leczenia było wykonanie szyn odciążających (w 81,9\% przypadków).

Należy potwierdzić skuteczność leczenia, bowiem u wszystkich pacjentów po przeprowadzeniu odpowiedniej terapii protetycznej, czyli wykonaniu płytki odciążającej oraz wspomagających zabiegach fizjoterapeutycznych, takich jak ćwiczenia mięśniowe Gerry'ego, oraz masażach mięśni, dolegliwości pourazowe szybko ustępowały.

\section{Oświadczenia}

Oświadczenie dotyczące konfliktu interesów

Autorzy deklarują brak konfliktu interesów w autorstwie oraz publikacji pracy.

\section{Źródła finansowania}

Autorzy deklarują brak źródeł finansowania.

\section{Piśmiennictwo}

[1] Haug R H, Prather J, Indresano A. An epidemiologic survey of facial fractures and concomitant injuries. J Oral Maxillofac Surg. 1990;48:926-932.

[2] Silvennoinen U, lizuka T, Oikarinen K, Lindqvist C. Analysis of possible factors leading to problems after nonsurgical treatment of condylar fractures. J Oral Maxillofac Surg. 1994;52:793-799.

[3] Will L A, West R A. Factors influencing the stability of sagittal split osteotomy for mandibular advancement. J Oral Maxillofac Surg. 1989;47:813-818.
[4] Ellis E, Simon P, Throckmorton G. Occlusal results after open or closed treatment of fractures of the mandibular condylar process. J Oral Maxillofac Surg. 2000;58:260268.

[5] Ellis E. Complications of mandibular condyle fractures. Int J Oral Maxillofac Surg. 1998;27:255-257.

[6] Laine P, Kontio R, Salo A, et al. Secondary correction of malocclusion after treatment of maxillofacial trauma. J Oral Maxillofac Surg. 2004;62:1312-1320.

[7] Becking A G, Zijderveld S A, Tuinzing D B. The surgical management of post-traumatic malocclusion. J Oral Maxillofac Surg. 1998;56:1370-1374.

[8] Proffit W R, Phillips C, Turvey T A. Stability following superior repositioning of the maxilla. Am J Orthod Dentofacial Orthop. 1987;92:151-163.

[9] Chalmers J LC. Fractures involving the mandibular condyle: a post-treatment survey of 120 cases. J Oral Surg. 1947;5:45-73.

[10] De Riu G, Gamba U, Anghinoni M, Sesenna E. A comparison of open and closed treatment of condylar fractures: a change in philosophy. Int $\mathrm{J}$ Oral Maxillofac Surg. 2001;30:384-389.

[11] Konstantinovic V S, Dimitrijevic B. Surgical versus conservative treatment of unilateral condylar process fractures: CLINICAL and radiographic evaluation of 80 patients. J Oral Maxillofac Surg. 1992;50:349-352.

[12] Ellis E, Throckmorton G S. Facial symmetry after closed and open treatment of fractures of the mandibular condylar process. J Oral Maxillofac Surg. 2000;58:719-728.

[13] Villarreal P M, Monje F, Junquera L M. Mandibular condyle fractures: determinants of treatment and outcome. J Oral Maxillofac Surg. 2004;62:155-163.

[14] Dahlström L, Kahnenberg K E, Lindahl L. 15-year follow-up on condylar fractures. Int $\mathrm{J}$ Oral Maxillofac Surg. 1989;18:18-23.

[15] Schendel S A, Epker B N. Results after mandibular advancement surgery: an analysis of 87 cases. J Oral Surg. 1980;38:265-282.

Zaakceptowano do edycji: 2017-09-01 Zaakceptowano do publikacji: 2017-11-02

Adres do korespondencji:

lek. dent. Andrzej Małysa

ul. Krakowska 26

50-425 Wrocław

e-mail: andrzejmalysa@o2.pl 